Original article

Section: Food Quality and Functionality

\title{
Effect of Transglutaminase and Bacterial Concentrates on the Development of Functional and Technological Properties of Minced Meat
}

\author{
Svetlana Merenkova ${ }^{1 *}$, Oksana Zinina $^{1}$, Olga Loretz ${ }^{2}$, Olga Neverova² ${ }^{2}$ Pavel Sharaviev ${ }^{2}$

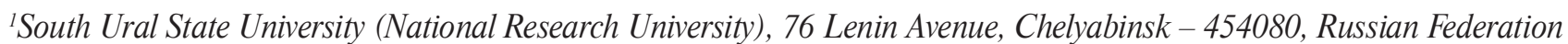 \\ ${ }^{2}$ Department of Technology, Ural State Agrarian University, Ekaterinburg, Russian Federation
}

Key words: minced meat, transglutaminase, bacterial concentrate, technological properties, rheological properties

The results of the effects of transglutaminase (TG) and bacterial concentrates (BC) of different strains of microorganisms on the functional and technological properties of minced meat obtained from beef trimming (80/20) are presented. A control and seven experimental samples of minced meat were obtained - three samples with the addition of $10 \%$ BC: Bifilact-Pro, Bifilact-AD, Bifilact-Kefir (S-Pro, S-AD, SK), a sample with the addition of $0.2 \%$ TG (S-TG) and three samples with simultaneous addition of 5\% BC: Bifilact-Pro, Bifilact-AD, Bifilact-Kefir and 0.1\% TG (S-Pro + TG, S-AD + TG, S-K + TG). The control and experimental samples were analyzed for: $\mathrm{pH}$, water binding capacity (WBC), water holding capacity (WHC), cooking loss, as well as physicochemical and rheological properties. The highest WHC was observed in the S-TG samples during the 6-12 h of ripening, whereas in the S-Pro+TG, S-AD+TG and S-K+TG samples during the ripening period of 12-18 h. The data obtained correlated with an increase in the $\mathrm{pH}$ value in the samples during the indicated periods. Significant differences were noted in the changes in WBC and WHC when BCs were added to the minced meat, as dependent on the composition of the microorganism cultures. The lowest cooking losses were determined in the S-TG sample, i.e. $19.03-19.99 \%(\mathrm{p}<0.05)$, whereas in the $\mathrm{S}-\mathrm{AD}+\mathrm{TG}$ and $\mathrm{S}-\mathrm{K}+\mathrm{TG}$ samples they reached $17.91-18.61 \%(\mathrm{p}<0.05)$ and $18.96-19.58 \%(\mathrm{p}<0.05)$, respectively. The most pronounced elastic properties were found in the samples with TG. Thus, the results showed that the combination of BC and TG demonstrates a synergistic effect on the functional and technological properties of meat systems.

\begin{abstract}
ABBREVIATIONS
TG - Transglutaminase; BC - Bacterial concentrate; WBC - Water binding capacity; WHC - Water holding capacity; EPS - Exopolysaccharides; LAB - Lactic acid bacteria.
\end{abstract}

\section{INTRODUCTION}

The rising cost of beef products has led to the need for the rational use of low-value meat cuts and beef trimmings as restructured meat, as prepared from small cuts of meat. This approach allows for an increase in the yield of marketable products and enterprises to gain additional profits [Sorapukdee \& Tangwatcharin, 2018].

In recent years, enzymatic processing of raw materials has become particularly popular with the intensive development of biotechnology [Cheng et al., 2009; Liu et al., 2012; Rawdkuen \& Benjakul, 2012]. Enzymatic modification of food components is more acceptable to the food industry than the more commonly used chemical methods [Kieliszek \& Misiewicz, 2014]. The experience of the practical use of enzymes for the processing of raw meat, as accumulated in many countries, suggests that this method of processing

\footnotetext{
* Corresponding Author:

E-mail: merenkovasp@susu.ru (S. Merenkova)
}

is very effective at improving the properties of raw materials and increasing the productive yield of meat products [Rivier, 2007; Rawdkuen \& Benjakul, 2012; Uran \& Yilmaz, 2018]. Transglutaminase (TG) plays an important role among these enzymes [Uran \& Yilmaz, 2018], with its potential to improve the firmness, viscosity, elasticity, and water binding capacity of food products [Kieliszek \& Misiewicz, 2014].

The use of TG in the meat industry improves the functional properties of proteins in meat products, contributes to the strong cohesion of a block of meat without the further need for the addition of salt or phosphates, and also has a positive effect on the texture of the final product, which results in an increase in its hardness [Kieliszek \& Misiewicz, 2014; Atilgan \& Kilic, 2017; Uran \& Yilmaz, 2018]. Meat products contain a high level of protein, including the myofibrillar proteins: actin and myosin, which affect the development of product texture and at the same time serve as good substrates for transglutaminase [Tseng et al., 2002].

TG helps solving technological problems in the production of both emulsified sausages and fine and coarse-minced sausages. The ability to bind proteins of different origins can be used in the production of combined meat products, allowing for the inclusion of lower-quality raw materials and ingredients, such as mechanically deboned meat, skimmed milk powder, soy or wheat flour. The use of TG allows for the production of lower fat content meat products which do not dif- 
fer in organoleptic properties from the conventional products [Kieliszek \& Misiewicz, 2014].

The results obtained by Sorapukdee \& Tangwatcharin [2018] and Baugreet et al. [2018] showed that pieces of restructured beef processed with microbial TG could be bound together via cross-linking of myosin chains and actin.

Many researchers point to the widespread use of bacterial preparations and starter microorganisms to improve the properties of raw meat [Campbell-Platt, 1995; Hammes \& Hertel, 1998; Ruiz-Moyano et al., 2008]. Many of these bacterial preparations include bifidobacteria and propionic acid bacteria [Ruiz-Moyano et al., 2008; Danylenko et al., 2014].

Exopolysaccharides (EPS) have an immense commercial value because of their industrially useful physico-chemical properties [Patel et al., 2012]. The polysaccharides excreted by lactic acid bacteria (LAB) during the fermentation processes result in the particular viscosity of certain foods [Sanni et al., 2002].

EPS are complex carbohydrates located outside the cell. Many strains of LAB produce extracellular polysaccharides which may be tightly associated with the bacterial cell wall as capsules or otherwise liberated into the growth medium as a loose slime [Cerning, 1995]. Some Bifidobacterium strains, as well as many other microorganisms, are able to produce these polymers [Ruas-Madiedo et al., 2007]. Dairy propionibacteria are also capable of producing EPS [Cerning, 1995].

EPS-producing lactic acid bacteria (EPS-producing cultures) are used to improve dairy product functionality by binding free water. EPS have the ability to bind water and to increase moisture retention by water binding or entrapment within their three-dimensional networks [El Soda, 2014]. EPS derived from LAB play a crucial role in improving the rheology, texture, and mouth feel of fermented food formulations and conferring beneficial physiological effects to human health [Doleyres et al., 2005].

However, the influence of TG in combination with bacterial concentrates (BC) on physicochemical and technological properties of meat products has not been reported to date in the relevant literature. Thus, the aim of this research was to determine the effect of transglutaminase and bacterial concentrates composed of different strains of microorganisms on the functional and technological properties of minced meat during the ripening process.

\section{MATERIALS AND METHODS}

\section{Materials}

Beef was collected $48 \mathrm{~h}$ after slaughtering from a breeding plant "Dubrovsky" (Chelyabinsk, Russia). Fresh beef trimmings (80/20) (66.42 g/100 g moisture, $16.10 \mathrm{~g} / 100 \mathrm{~g}$ protein, and $17.64 \mathrm{~g} / 100 \mathrm{~g}$ fat) were obtained from rib and round portions. Beef trimmings were transported in a refrigerator at $4^{\circ} \mathrm{C}$ to the laboratory of the Food and Biotechnology Department (South Ural State University, Chelyabinsk, Russia) within $2 \mathrm{~h}$ for further processing. Then, beef trimming was analyzed for pH using a portable $\mathrm{pH}$-meter (HANNA HI83141, Woonsocket, RI, USA). An electrode was inserted to a depth of $5 \pm 1 \mathrm{~cm}$, where the values obtained ranged from 5.56 to 5.62.

Bacterial concentrates (BCs): Bifilact-Pro, Bifilact-AD and BK-Kefir, were produced by the Federal State Unitary
Enterprise "An Experimental Biofactory" of the Russian Agricultural Academy (Uglich, Russian Federation):

- concentrate Bifilact-Pro consists of Lactococcus lactis subsp. diacetilactis, Streptococcus thermophilus, Propionibacterium freudenreichii, Bifidobacterium Bifidum, Bifidobacterium longum, Bifidobacterium adolescentis species;

- concentrate Bifilact-AD consists of Lactococcus lactis subsp. diacetilactis, Streptococcus thermophilus, Lactobacillus acidophilus, Bifidobacterium Bifidum, Bifidobacterium longum, Bifidobacterium adolescentis species;

- concentrate BK-Kefir consists of Lactococcus lactis subsp. Lactis, Lac. lactis subsp. Cremoris, Lac. lactis subsp. Diacetilactis, Leuconostoc mesenteroides subsp. Cremoris, Streptococcus thermophiles, Lactobacillus plantarum, Lbc. fermentum, L. casei, Acetobacter aceti.

Transglutaminase is an enzyme preparation produced by cultivation of Streptomyces mobaraensis (BioBond Shanghai's Kinry Pharmaceutical Co., Ltd. Shanghai, China).

\section{Preparation of minced meat samples}

The beef trimmings $(80 / 20)$ were passed through a grinder (Fimar 32/RS Unger, Italy) fitted with a plate with $6 \mathrm{~mm}$ diameter holes.

BCs were activated in $1 \mathrm{~L}$ of sterilized skimmed milk at a temperature of $37 \pm 1{ }^{\circ} \mathrm{C}$. Microbial TG was added to the meat in a dry form, and water was added to activate it. For the research, control and test samples were made - experimental samples of minced meat with the introduction of $10 \%$ BCs by weight of raw materials (S-Pro - sample with concentrate Bifilact-Pro, S-AD - sample with concentrate Bifilact-AD, S-K - sample with concentrate BK-Kefir), experimental samples of minced meat with the addition of $0.2 \%$ TG by weight of raw materials (S-TG), and experimental samples

TABLE 1. Formulation of samples.

\begin{tabular}{|c|c|c|c|c|}
\hline \multirow{2}{*}{ Samples } & \multicolumn{2}{|c|}{$\begin{array}{c}\text { Components } \\
(\mathrm{kg} \text { per } 100 \mathrm{~kg} \\
\text { of minced meat) }\end{array}$} & \multicolumn{2}{|c|}{$\begin{array}{c}\text { Biotechnological additives } \\
(\mathrm{kg} \text { per } 100 \mathrm{~kg} \\
\text { of minced meat })\end{array}$} \\
\hline & $\begin{array}{c}\text { beef } \\
\text { trimmings } \\
(80 / 20)\end{array}$ & water & TG & $\begin{array}{c}\text { bacterial } \\
\text { concentrate }\end{array}$ \\
\hline S-C & 90 & 10 & 0 & 0 \\
\hline S-Pro & 90 & 0 & 0 & 10 \\
\hline S-AD & 90 & 0 & 0 & 10 \\
\hline S-K & 90 & 0 & 0 & 10 \\
\hline S-TG & 90 & 10 & 0.2 & 0 \\
\hline S-Pro+TG & 90 & 5 & 0.1 & 5 \\
\hline $\mathrm{S}-\mathrm{AD}+\mathrm{TG}$ & 90 & 5 & 0.1 & 5 \\
\hline $\mathrm{S}-\mathrm{K}+\mathrm{TG}$ & 90 & 5 & 0.1 & 5 \\
\hline
\end{tabular}

Note: S-C - control sample; S-Pro, S-AD, S-K - samples with the addition of $10 \%$ concentrate Bifilact-Pro, Bifilact-AD, Bifilact-Kefir; S-TG- samples with the addition of $0.2 \%$ transglutaminase; S-Pro+TG, $\mathrm{S}-\mathrm{AD}+\mathrm{TG}, \mathrm{S}-\mathrm{K}+\mathrm{TG}$ - samples with the addition of $0.1 \%$ transglutaminase and 5\% Bifilact-Pro, Bifilact-AD, Bifilact-Kefir. 
with simultaneous addition of $0.1 \%$ enzyme TG and $5 \% \mathrm{BC}$ by weight of raw materials (S-Pro+TG - sample with concentrate Bifilact-Pro and TG, S-AD+TG - sample with concentrate Bifilact-AD and TG, S-K+TG - sample with concentrate BK-Kefir and TG). A sample of the minced meat from the trimmings was taken as the control sample $(\mathrm{S}-\mathrm{C})$. Thus, a total of eight formulations were taken (Table 1), where five samples of minced meat were made for each formulation.

Prepared minced meat samples were kept for ripening at a temperature of $2 \pm 2^{\circ} \mathrm{C}$ for $24 \mathrm{~h}$, and parts of the samples were taken to determine indicators characterizing the functional and technological properties of minced meat $(\mathrm{pH}$, water binding capacity (WBC), water holding capacity (WHC), cooking loss and rheological properties) every $6 \mathrm{~h}(0,6,12$, $18,24 \mathrm{~h})$

\section{Technological properties measurements}

\section{Water binding capacity}

The WBC was determined via the filter paper method [Grau \& Hamm, 1956], which is based on determining the amount of separated moisture after lightly pressing and calculating the spot area formed on a piece of filter paper using a planimeter. The mass fraction of the bound moisture in a given sample was calculated using the following formula:

$$
\mathrm{X}=(\mathrm{A}-8.4 \times \mathrm{B}) \times 100 \mathrm{~A},
$$

where: $\mathrm{X}$ - mass fraction of bound water in a sample (\% total moisture), A - total mass of moisture in a sample (mg), and B - area of the wet spot $\left(\mathrm{mm}^{2}\right)$.

\section{Water holding capacity}

The WHC was determined gravimetrically as described by Zhang et al. [2018]. Samples were placed in sealed centrifuge tubes and centrifuged at $70 \times g$ for $15 \mathrm{~min}$ at $4^{\circ} \mathrm{C}$ (Laboratory centrifuge "OKA", Sibagroprom, Novosibirsk, Russia). After heating at $75^{\circ} \mathrm{C}$, the supernatant was decanted, and samples were weighed. The samples were then stored at $4^{\circ} \mathrm{C}$ for $24 \mathrm{~h}$ and centrifuged at $110 \times g$ for $10 \mathrm{~min}$ at $4^{\circ} \mathrm{C}$ (Laboratory centrifuge "OKA", Sibagroprom, Novosibirsk, Russia). The resulting supernatant was removed using filter paper and samples were weighed. Water holding capacity (\%) was expressed using the following formula:

$$
\mathrm{WHC}(\%)=\left[\left(\mathrm{W}_{2}-\mathrm{W}\right) /\left(\mathrm{W}_{1}-\mathrm{W}\right)\right] \times 100 \%
$$

where: $\mathrm{W}$ - mass of the sample $(\mathrm{g}), \mathrm{W}_{1}$ - mass of the sample after heating and decanting the supernatant $(\mathrm{g})$, and $\mathrm{W}_{2}-$ mass of the sample after centrifuging and removal of resulting supernatant $(\mathrm{g})$.

\section{Cooking loss}

Weight loss of minced meat during heat treatment was determined using the gravimetric method, based on measuring the mass of a sample before and after heat treatment. To determine cooking loss, the minced meat was formed into meatballs weighing $11 \pm 1 \mathrm{~g}$ each, which were weighed before heating at $75^{\circ} \mathrm{C}$ in the air-o-steam (Rational AG, Landsberg am Lech, Germany) for 10 min. Cooking loss was calculated using the following formula:

Cooking loss $(\%)=[$ (weight of raw sample $(\mathrm{g})$-weight of cooked sample $(\mathrm{g}) /$ weight of raw sample $(\mathrm{g})] \times 100$.

\section{pH}

To determine $\mathrm{pH}$ values, $5 \mathrm{~g}$ of minced meat sample was blended with $20 \mathrm{~mL}$ of distilled water for 1 min using a chopper [Bosch MMR 0801, Gerlingen, Germany]. The pH was measured with a stationary $\mathrm{pH}$ meter (model HANNA HI $2210(\mathrm{PH} / \mathrm{T})$, Woonsocket, RI, USA) equipped with a pH and temperature electrode HI 1131B and HI 7662 (HANNA) at $20^{\circ} \mathrm{C}$. Before measuring $\mathrm{pH}$, the detector was calibrated with $\mathrm{pH} 4.01$ and $\mathrm{pH} 6.86$ buffers.

\section{Rheological measurements}

Rheological measurements were conducted using a texture analyzer "Structurometer ST2" (LAB, Quality Laboratory, Moscow, Russia) by compressing it with an indenter "Cylinder Ø36" (duralumin, mass $42.5 \mathrm{~g}$ ). The analysis of the mechanical tension induced on a cylindrical indenter during its introduction into the product was carried out under the following loading mode: contact force $(\mathrm{Fc}=7 \mathrm{~g})$, strain rate $(\mathrm{Vd}$ $=0.5 \mathrm{~mm} / \mathrm{s}$ ), and the introduction of the indenter continued until the effort Fmax $=500 \mathrm{~g}$. Total, plastic, and elastic deformations were determined. Measurements were carried out at a sample temperature of $2 \pm 2^{\circ} \mathrm{C}$.

\section{Physicochemical analyses}

Chemical analyses of the minced meat samples were performed $24 \mathrm{~h}$ after their preparation. Total nitrogen content was assayed using the Kjeldahl method [ISO 937:1978]. Nitrogen was converted to equivalent protein content using a factor of 6.25. Moisture was determined according to ISO standard [ISO 1442:1997]. Total fat was determined by the Soxhlet method according to ISO standard [ISO 1444:2000].

\section{Statistical analysis}

The experiment was carried out in five replicates and each analysis was performed in three repetitions. All measurements were conducted in triplicate. Results were expressed as mean values of five replicates \pm standard deviation. Probability values $p \leq 0.05$ were taken to indicate statistical significance. The data was analyzed via one-way ANOVA and the Tukey test using the free web-based software offered by Assaad et al. [2014].

\section{RESULTS AND DISCUSSION}

\section{pH, WBC, WHC and cooking loss}

TG maintains its maximal enzymatic activity at temperatures close to $0^{\circ} \mathrm{C}$ [Yokoyama et al., 2004], allowing it to be used at the low temperatures required for meat ripening.

The research results (Table 2) demonstrated that the $\mathrm{pH}$ of minced meat changed depending on the concentration of biotechnological components and length of the ripening period. In the control sample, a gradual increase in the $\mathrm{pH}$ to 5.82 by the end of the ripening period was observed, which 
TABLE 2. The $\mathrm{pH}$ value of minced meat samples during ripening.

\begin{tabular}{l|c|c|c|c|c}
\hline Samples & $0 \mathrm{~h}$ & $6 \mathrm{~h}$ & $12 \mathrm{~h}$ & $18 \mathrm{~h}$ & $24 \mathrm{~h}$ \\
\hline S-C & $5.53 \pm 0.004^{\mathrm{eA}}$ & $5.56 \pm 0.005^{\mathrm{dD}}$ & $5.66 \pm 0.004^{\mathrm{cE}}$ & $5.76 \pm 0.005^{\mathrm{bD}}$ & $5.82 \pm 0.005^{\mathrm{aC}}$ \\
S-Pro & $5.46 \pm 0.005^{\mathrm{bcB}}$ & $5.48 \pm 0.007^{\mathrm{bE}}$ & $5.50 \pm 0.004^{\mathrm{aF}}$ & $5.46 \pm 0.005^{\mathrm{cF}}$ & $5.34 \pm 0.004^{\mathrm{dE}}$ \\
S-AD & $5.45 \pm 0.004^{\mathrm{dB}}$ & $5.49 \pm 0.004^{\mathrm{cE}}$ & $5.52 \pm 0.005^{\mathrm{bF}}$ & $5.56 \pm 0.004^{\mathrm{aE}}$ & $5.46 \pm 0.004^{\mathrm{dD}}$ \\
S-K & $5.45 \pm 0.004^{\mathrm{bB}}$ & $5.50 \pm 0.004^{\mathrm{aE}}$ & $5.44 \pm 0.003^{\mathrm{bG}}$ & $5.40 \pm 0.005^{\mathrm{cG}}$ & $5.37 \pm 0.003^{\mathrm{dE}}$ \\
\hline S-TG & $5.51 \pm 0.004^{\mathrm{cA}}$ & $5.87 \pm 0.005^{\mathrm{bA}}$ & $5.93 \pm 0.004^{\mathrm{aC}}$ & $5.88 \pm 0.007^{\mathrm{bC}}$ & $5.86 \pm 0.004^{\mathrm{bB}}$ \\
S-Pro+TG & $5.45 \pm 0.002^{\mathrm{dB}}$ & $5.65 \pm 0.005^{\mathrm{cC}}$ & $5.88 \pm 0.005^{\mathrm{aD}}$ & $5.86 \pm 0.005^{\mathrm{bC}}$ & $5.84 \pm 0.004^{\mathrm{bBC}}$ \\
S-AD+TG & $5.45 \pm 0.004^{\mathrm{eB}}$ & $5.69 \pm 0.005^{\mathrm{dC}}$ & $5.97 \pm 0.004^{\mathrm{aB}}$ & $5.95 \pm 0.004^{\mathrm{bB}}$ & $5.90 \pm 0.007^{\mathrm{cA}}$ \\
S-K+TG & $5.46 \pm 0.005^{\mathrm{dB}}$ & $5.76 \pm 0.004^{\mathrm{cB}}$ & $6.02 \pm 0.004^{\mathrm{aA}}$ & $6.00 \pm 0.007^{\mathrm{aA}}$ & $5.94 \pm 0.006^{\mathrm{bA}}$ \\
\hline
\end{tabular}

Note: data are the mean values of five replicates \pm standard deviation $(n=5)$. Means in a row without a common superscript letter $a, b, c-$ are statistically significantly different $(p<0.05)$. Means in a column without a common superscript letter A, B, C - are statistically significantly different $(p<0.05)$ as analyzed by one-way ANOVA and the TUKEY test.

S-C - control sample; S-Pro, S-AD, S-K - samples with the addition of 10\% concentrate Bifilact-Pro, Bifilact-AD, Bifilact-Kefir; S-TG - samples with the addition of $0.2 \%$ transglutaminase; S-Pro + TG, S-AD+TG, S-K+TG - samples with the addition of $0.1 \%$ transglutaminase and $5 \%$ Bifilact-Pro, Bifilact-AD, Bifilact-Kefir.

is typical of a meat system that does not contain technological additives.

The $\mathrm{pH}$ values of minced systems varied from 5.45 to 5.53 before the start of the ripening process. From results presented in Table 2, it can be concluded that the introduction of $\mathrm{BC}$ in a $10 \%$ concentration led to a successive increase in the acidity of the meat system and a decrease in $\mathrm{pH}$ to 5.34-5.46 after $24 \mathrm{~h}$ of fermentation. This effect is due to the accumulation of acidic metabolic products of bacteria that will reduce the $\mathrm{pH}$ as a fact of their acidity [Mejri et al., 2017]. Moreover, the accumulation of the acidic products of microbial activity in minced meat was irregular throughout the ripening period; in the samples containing BC - S-AD and S-Pro (10\%), there was a significant increase in $\mathrm{pH}$ to $5.50-5.56(p<0.05)$ after $12-18 \mathrm{~h}$ of ripening, followed by a successive decrease.

There was a significant increase in $\mathrm{pH}$ in the samples containing TG compared with the control samples after 12-18 h of ripening The maximum $\mathrm{pH}$ level in the S-TG samples was observed during the 6-12 $\mathrm{h}$ interval (5.87-5.93), and for the samples containing a complex of TG and BC (S-AD+TG and S-K+TG) at 12-18 h (5.97-6.02). Meiying et al. [2002] demonstrated that the $\mathrm{pH}$ of meat batter treated with TG was higher than that of meat without TG treatment. The $\mathrm{pH}$ value established in the samples of minced meat with TG was remote from the isoelectric point of muscle proteins, which significantly affected their functional properties, ensuring a high level of WBC, WHC, and low weight loss during heat treatment. Hughes et al. [2014] reported that loss of water from muscles and the degree of changes in their properties depends on the $\mathrm{pH}$ which muscle proteins are sensitive to.

Significant differences in the dynamics of WBC were noted depending on the composition of microorganisms in experimental samples with $\mathrm{BC}$ (Table 3). In sample $\mathrm{S}-\mathrm{K}$, WBC increased slightly and reached its maximum during 6-12 $\mathrm{h}$ of the ripening period. There was a rapid increase in WBC, which reached a maximum by $12-18 \mathrm{~h}$ of ripening, when a starter containing acidophilic and propionic acid cul- tures (samples S-AD and S-Pro) was added to the minced meat. It should be emphasized that the addition of BC Bifilact-Pro and Bifilact-AD significantly improved the water binding capacity of the meat system after $12 \mathrm{~h}$ of maturation to $51.8-52.1 \%(p<0.05)$ compared to the control. Cerning [1995] and Patel et al. [2012] proved that lactic acid bacteria and propionic bacteria are capable of producing EPS at low temperatures and $\mathrm{pH}$ levels close to 5.5. It can be assumed that the improvement in water binding capacity observed for S-Pro and S-AD samples is due to the water-absorbing properties of EPS, which accumulate during the vital activity of these types of bacteria. However, there was a considerable decrease in WBC of minced meat with bacterial starters to $39.9-46.3 \%(p<0.05)$ by the end of the ripening process (24 h), which was apparently due to the accumulation of lactic acid and the consequent decrease in $\mathrm{pH}$ to that close to the isoelectric point of muscle proteins. Mauriello et al. [2004] noted that WBC decrease is related to $\mathrm{pH}$ decrease; when $\mathrm{pH}$ is close to the isoelectric point of the protein, the functional properties of the meat proteins are reduced. Puolanne et al. [2013] researched the WHC of meat without added salt, which was found to have a distinct minimum at $\mathrm{pH}$ 5.0, which is the average isoelectric $\mathrm{pH}$ of meat structural proteins.

It should be emphasized that the combination of $\mathrm{BC}$ and TG has a synergistic effect on the functional and technological properties of minced systems. Thus, when TG and BC are added to minced meat, the protein matrix is rapidly formed during the first 6-12 h of exposure; the technological properties of meat are enhanced as a result of TG activity. This has been confirmed by the research results. The highest WBC was observed in the S-TG samples during the first 6-12 h of maturation, whereas in the S-Pro+TG, S-AD+TG, and S-K+TG samples - in 12-18 h of the maturation period. The data obtained correlate with an increase in $\mathrm{pH}$ of the meat system during the indicated periods. In addition, in the samples containing the complex of TG and bacterial cultures, the WBC increased considerably to 58.6-65.0\% $(p<0.05)$ as compared 
TABLE 3. The functional and technological properties of minced meat samples.

\begin{tabular}{|c|c|c|c|c|c|}
\hline Samples & $0 \mathrm{~h}$ & $6 \mathrm{~h}$ & $12 \mathrm{~h}$ & $18 \mathrm{~h}$ & $24 \mathrm{~h}$ \\
\hline \multicolumn{6}{|c|}{$W B C(\%)$} \\
\hline S-C & $39.70 \pm 0.014^{\mathrm{eH}}$ & $42.03 \pm 0.062^{\mathrm{dF}}$ & $49.45 \pm 0.017^{\mathrm{cG}}$ & $50.24 \pm 0.057^{\mathrm{bE}}$ & $50.83 \pm 0.03^{\mathrm{aE}}$ \\
\hline S-Pro & $44.53 \pm 0.014^{\mathrm{dC}}$ & $46.62 \pm 0.015^{\mathrm{cD}}$ & $52.10 \pm 0.013^{\mathrm{aE}}$ & $49.91 \pm 0.015^{\mathrm{bF}}$ & $39.90 \pm 0.016^{\mathrm{eH}}$ \\
\hline S-AD & $41.29 \pm 0.012^{\mathrm{eG}}$ & $42.80 \pm 0.013^{\mathrm{dE}}$ & $51.75 \pm 0.014^{\mathrm{aF}}$ & $50.50 \pm 0.013^{\mathrm{bD}}$ & $46.35 \pm 0.019^{\mathrm{cF}}$ \\
\hline S-K & $44.61 \pm 0.012^{\mathrm{cA}}$ & $46.60 \pm 0.013^{\mathrm{aD}}$ & $45.11 \pm 0.012^{\mathrm{bH}}$ & $44.34 \pm 0.012^{\mathrm{dG}}$ & $43.93 \pm 0.016^{\mathrm{eG}}$ \\
\hline S-TG & $45.44 \pm 0.011^{\mathrm{eB}}$ & $59.56 \pm 0.015^{\mathrm{aA}}$ & $58.49 \pm 0.063^{\mathrm{bD}}$ & $55.10 \pm 0.017^{\mathrm{cB}}$ & $54.80 \pm 0.015^{\mathrm{dC}}$ \\
\hline S-Pro+TG & $41.52 \pm 0.015^{\mathrm{eF}}$ & $46.66 \pm 0.013^{\mathrm{dD}}$ & $61.58 \pm 0.015^{\mathrm{aC}}$ & $57.04 \pm 0.086^{\mathrm{bC}}$ & $53.46 \pm 0.016^{\mathrm{cA}}$ \\
\hline $\mathrm{S}-\mathrm{AD}+\mathrm{TG}$ & $43.17 \pm 0.013^{\mathrm{eE}}$ & $48.42 \pm 0.015^{\mathrm{dC}}$ & $64.68 \pm 0.014^{\mathrm{aB}}$ & $58.66 \pm 0.015^{\mathrm{bA}}$ & $55.91 \pm 0.016^{\mathrm{cB}}$ \\
\hline $\mathrm{S}-\mathrm{K}+\mathrm{TG}$ & $43.53 \pm 0.018^{\mathrm{eD}}$ & $55.57 \pm 0.012^{\mathrm{cв}}$ & $65.03 \pm 0.023^{\mathrm{aA}}$ & $58.77 \pm 0.013^{\mathrm{bA}}$ & $54.37 \pm 0.014^{\mathrm{dD}}$ \\
\hline \multicolumn{6}{|c|}{ Cooking loss (\%) } \\
\hline S-C & $27.35 \pm 0.14^{\mathrm{aBC}}$ & $26.08 \pm 0.16^{\mathrm{bB}}$ & $25.40 \pm 0.08^{\mathrm{cB}}$ & $24.34 \pm 0.15^{\mathrm{dC}}$ & $24.03 \pm 0.08^{\mathrm{dD}}$ \\
\hline S-Pro & $27.91 \pm 0.15^{\mathrm{aA}}$ & $27.18 \pm 0.09^{\mathrm{bA}}$ & $24.96 \pm 0.08^{\mathrm{dB}}$ & $25.58 \pm 0.09^{\mathrm{cB}}$ & $28.09 \pm 0.08^{\mathrm{aA}}$ \\
\hline S-AD & $27.75 \pm 0.14^{\mathrm{aAB}}$ & $26.20 \pm 0.1^{\mathrm{bB}}$ & $23.54 \pm 0.17^{\mathrm{dC}}$ & $23.05 \pm 0.09^{\mathrm{dD}}$ & $24.94 \pm 0.05^{\mathrm{cC}}$ \\
\hline S-K & $28.02 \pm 0.1^{\mathrm{aA}}$ & $26.76 \pm 0.09^{\mathrm{cA}}$ & $26.17 \pm 0.11^{\mathrm{dA}}$ & $27.75 \pm 0.13^{\mathrm{abA}}$ & $27.32 \pm 0.12^{\mathrm{bB}}$ \\
\hline S-TG & $26.45 \pm 0.05^{\mathrm{aE}}$ & $19.99 \pm 0.14^{\mathrm{dE}}$ & $19.03 \pm 0.07^{\mathrm{eE}}$ & $21.4 \pm 0.03^{\mathrm{cE}}$ & $23.68 \pm 0.04^{\mathrm{bE}}$ \\
\hline S-Pro+TG & $27.62 \pm 0.06^{\mathrm{aAB}}$ & $25.25 \pm 0.05^{\mathrm{bC}}$ & $20.27 \pm 0.2^{\mathrm{eD}}$ & $21.71 \pm 0.1^{\mathrm{dE}}$ & $22.35 \pm 0.05^{\mathrm{cF}}$ \\
\hline $\mathrm{S}-\mathrm{AD}+\mathrm{TG}$ & $26.96 \pm 0.05^{\mathrm{aCD}}$ & $24.78 \pm 0.07^{\mathrm{bD}}$ & $17.91 \pm 0.06^{\mathrm{eF}}$ & $18.61 \pm 0.09^{\mathrm{dG}}$ & $20.92 \pm 0.04^{\mathrm{cH}}$ \\
\hline $\mathrm{S}-\mathrm{K}+\mathrm{TG}$ & $26.68 \pm 0.04^{\mathrm{aDE}}$ & $24.33 \pm 0.04^{\mathrm{bD}}$ & $18.96 \pm 0.04^{\mathrm{eE}}$ & $19.58 \pm 0.09^{\mathrm{dF}}$ & $21.60 \pm 0.03^{\mathrm{cG}}$ \\
\hline \multicolumn{6}{|c|}{$W H C(\%)$} \\
\hline S-C & $35.36 \pm 0.179^{\mathrm{bA}}$ & $38.72 \pm 0.168^{\mathrm{aD}}$ & $38.84 \pm 0.201^{\mathrm{aC}}$ & $39.12 \pm 0.252^{\mathrm{aD}}$ & $39.33 \pm 0.256^{\mathrm{aD}}$ \\
\hline S-Pro & $33.83 \pm 0.195^{\mathrm{eB}}$ & $35.94 \pm 0.246^{\mathrm{dE}}$ & $37.2 \pm 0.259^{\mathrm{cD}}$ & $36.7 \pm 0.214^{\mathrm{abE}}$ & $35.9 \pm 0.272^{\mathrm{aE}}$ \\
\hline S-AD & $35.2 \pm 0.199^{\mathrm{eA}}$ & $36.48 \pm 0.227^{\mathrm{dE}}$ & $37.86 \pm 0.24^{\mathrm{cCD}}$ & $37.3 \pm 0.259^{\mathrm{abE}}$ & $36.2 \pm 0.251^{\mathrm{aE}}$ \\
\hline S-K & $34.99 \pm 0.156^{\mathrm{dA}}$ & $36.54 \pm 0.242^{\mathrm{cE}}$ & $38.14 \pm 0.22^{\mathrm{bCD}}$ & $37.9 \pm 0.182^{\mathrm{abDE}}$ & $37.2 \pm 0.283^{\mathrm{bcE}}$ \\
\hline S-TG & $34.62 \pm 0.23^{\mathrm{dAB}}$ & $48.12 \pm 0.177^{\mathrm{abA}}$ & $48.62 \pm 0.188^{\mathrm{aA}}$ & $47.34 \pm 0.28^{\mathrm{bcC}}$ & $46.84 \pm 0.298^{\mathrm{cC}}$ \\
\hline S-Pro+TG & $34.87 \pm 0.161^{\mathrm{dA}}$ & $43.24 \pm 0.232^{\mathrm{cC}}$ & $45.9 \pm 0.228^{\text {ьв }}$ & $48.16 \pm 0.31^{\mathrm{aBC}}$ & $49.08 \pm 0.334^{\mathrm{aB}}$ \\
\hline $\mathrm{S}-\mathrm{AD}+\mathrm{TG}$ & $35.06 \pm 0.171^{\mathrm{dA}}$ & $44.88 \pm 0.159^{\mathrm{cв}}$ & $46.58 \pm 0.304^{\mathrm{bB}}$ & $49.28 \pm 0.36^{\mathrm{aAB}}$ & $49.84 \pm 0.317^{\mathrm{aB}}$ \\
\hline $\mathrm{S}-\mathrm{K}+\mathrm{TG}$ & $33.94 \pm 0.144^{\mathrm{dB}}$ & $44.19 \pm 0.25^{\mathrm{cBC}}$ & $46.34 \pm 0.273^{\mathrm{bB}}$ & $50.16 \pm 0.296^{\mathrm{aA}}$ & $51.23 \pm 0.328^{\mathrm{aA}}$ \\
\hline
\end{tabular}

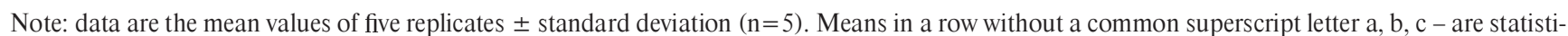
cally significantly different $(p<0.05)$. Means in a column without a common superscript letter A, B, C - are statistically significantly different $(p<0.05)$ as analyzed by one-way ANOVA and the TUKEY test.

S-C - control sample; S-Pro, S-AD, S-K - samples with the addition of 10\% concentrate Bifilact-Pro, Bifilact-AD, Bifilact-Kefir; S-TG - samples with the addition of $0.2 \%$ transglutaminase; S-Pro+TG, S-AD +TG, S-K+TG - samples with the addition of $0.1 \%$ transglutaminase and 5\% Bifilact-Pro, Bifilact-AD, Bifilact-Kefir; WBC - water binding capacity; WHC - water holding capacity.

with samples containing only the TG in $12-18 \mathrm{~h}$ of the ripening period. A slight decrease in WBC to $53.5-55.9 \%(p<0.05)$ was observed in these samples during the last exposure period, which can be associated with the rising proteolytic activity of the microorganisms and which leads to partial destruction of the protein matrix.

In the literature, there is contradictory information about the influence of TG on WBC and cooking loss, respectively. Some studies have found that TG does not significantly affect product loss [Uran et al., 2013], while others point to the negative impact of TG on cooking loss [Atilgan \& Kilic, 2017]. Atilgan \& Kilic [2017] demonstrated that the use of microbial TG had a negative effect on WBC and caused increased cooking loss in muscle-based foods. Aaslyng et al. [2003] noted the correlation between the WHC of raw pork muscle and cooking loss which was dependent on cooking temperature.

The results of our research showed that decreasing WHC and WBC was correlated to increased cooking loss. Significant differences in weight loss compared to the control sample 
TABLE 4. Contents of major components of minced meat samples.

\begin{tabular}{l|c|c|c}
\hline Samples & $\begin{array}{c}\text { Fat } \\
(\mathrm{g} / 100 \mathrm{~g})\end{array}$ & $\begin{array}{c}\text { Protein } \\
(\mathrm{g} / 100 \mathrm{~g})\end{array}$ & $\begin{array}{c}\text { Moisture } \\
(\mathrm{g} / 100 \mathrm{~g})\end{array}$ \\
\hline S-C & $17.82 \pm 0.13^{\mathrm{a}}$ & $16.36 \pm 0.10^{\mathrm{ab}}$ & $65.16 \pm 0.26^{\mathrm{d}}$ \\
S-Pro & $16.56 \pm 0.07^{\mathrm{bc}}$ & $15.58 \pm 0.09^{\mathrm{cd}}$ & $67.08 \pm 0.29^{\mathrm{abc}}$ \\
S-AD & $16.50 \pm 0.17^{\mathrm{c}}$ & $15.18 \pm 0.11^{\mathrm{d}}$ & $67.40 \pm 0.26^{\mathrm{ab}}$ \\
S-K & $16.22 \pm 0.11^{\mathrm{c}}$ & $15.44 \pm 0.12^{\mathrm{d}}$ & $67.68 \pm 0.32^{\mathrm{a}}$ \\
S-TG & $17.22 \pm 0.27^{\mathrm{ab}}$ & $16.58 \pm 0.16^{\mathrm{a}}$ & $66.00 \pm 0.23^{\mathrm{cd}}$ \\
S-Pro+TG & $16.64 \pm 0.14^{\mathrm{bc}}$ & $16.20 \pm 0.07^{\mathrm{abc}}$ & $66.42 \pm 0.22^{\mathrm{ad}}$ \\
S-AD+TG & $16.90 \pm 0.17^{\mathrm{bc}}$ & $15.88 \pm 0.19^{\mathrm{ad}}$ & $66.26 \pm 0.18^{\mathrm{bd}}$ \\
S-K+TG & $16.90 \pm 0.12^{\mathrm{bc}}$ & $15.78 \pm 0.14^{\mathrm{bd}}$ & $66.56 \pm 0.13^{\mathrm{abc}}$ \\
\hline
\end{tabular}

Note: data are the mean values of five replicates \pm standard deviation $(\mathrm{n}=5)$. Means in a column without a common superscript letter $\mathrm{a}, \mathrm{b}, \mathrm{c}$ - are statistically significantly different $(p<0.05)$ as analyzed by one-way ANOVA and the TUKEY test.

S-C - control sample; S-Pro, S-AD, S-K - samples with the addition of $10 \%$ concentrate Bifilact-Pro, Bifilact-AD, Bifilact-Kefir; S-TG - samples with the addition of $0.2 \%$ transglutaminase; S-Pro+TG, S-AD+TG $\mathrm{S}-\mathrm{K}+\mathrm{TG}$ - samples with the addition of $0.1 \%$ transglutaminase and $5 \%$ Bifilact-Pro, Bifilact-AD, Bifilact-Kefir.

were found only in the S-TG and S-K+TG samples at the initial stage of maturation $(0 \mathrm{~h})$ (Table 3$)$, while in the 18-24 h period, a considerable reduction in cooking loss in comparison to the control was established for all samples containing TG enzyme $(0.1$ and $0.2 \%)$. Thus, the greatest mass loss was observed in the samples without TG (S-C, S-Pro, S-AD, $\mathrm{S}-\mathrm{K})$, and this tendency was found to continue from $6 \mathrm{~h}$ until the end of the maturation process. The lowest cooking loss was observed in samples with high WBC and WHC. Thus, in the S-TG sample, the lowest cooking losses were established between $6-12 \mathrm{~h}$ and reached $19.03-19.99 \%(p<0.05)$, whilst in the S-AD+TG and S-K+TG samples the lowest weight loss was found in the $12-18 \mathrm{~h}$ period and amounted to $17.91-$ $-18.61 \%(p<0.05)$ and $18.96-19.58 \%(p<0.05)$, respectively.

Pietrasik et al. [2007] noted that TG increases the WHC of meat products and decreases cooking loss, which is in agreement with the results reported above. Zeng et al. [2017] determined that the degradation of myofibrils as a result of enzyme proteolytic activity led to improved water holding in myofibrils. The results obtained confirm that not only does the TG activity have a positive effect on WHC, but further that the microorganisms in BC possessing the ability to synthesize EPS, which are hydrocolloids, enhance the ability of the meat system to hydrate. Consequently, the highest values of WHC were detected in the samples with TG, i.e. $48.6 \%(p<0.05)$ in sample S-TG at $12 \mathrm{~h}$ of maturation, 51.2 and $49.8 \%(p<0.05)$ in samples $\mathrm{S}-\mathrm{K}+\mathrm{TG}$ and $\mathrm{S}-\mathrm{AD}+\mathrm{TG}$, respectively at $24 \mathrm{~h}$ of maturation.

Accordingly, the results obtained confirm the synergistic effect of the activity of TG and BC on the development of the functional and technological properties of the meat system. Exposure for 12-18 h was found to be optimal for the development of the required technological qualities of minced meat with the addition of $\mathrm{TG}$ and $\mathrm{BC}$.

\section{Chemical composition}

The results of determination of minced meat physicochemical indicators are presented in Table 4. The results obtained demonstrate that applying various biotechnological additives resulted in a significant decrease in the fat content in the experimental groups compared with the control group $(p<0.05)$. Protein contents of the samples containing BCs (S-Pro, S-AD, S-K) were significantly reduced $(p<0.05)$ in comparison to those in the control sample and samples with TG, which was probably due to the lower water binding capacity and water holding capacity of these samples and caused loss of nutrients. The moisture content of the samples with BCs (S-Pro, S-AD, S-K) was 67.1, 67.4, and $67.7 \mathrm{~g} / 100 \mathrm{~g}$, respectively, while the moisture content of the samples with TG (S-TG, S-Pro+TG, S-AD+TG, S-K+TG) ranged from 66.0 to $66.6 \mathrm{~g} / 100 \mathrm{~g}$. According to Atilgan \& Kilic [2017], the use of TG did not cause significant differences in protein contents among groups of cooked ground beef. The protein content in our studies ranged from 15.2 to $16.6 \mathrm{~g} / 100 \mathrm{~g}$ $(p<0.05)$; no statistically significant differences were found in its values in the control and experimental groups with TG $(0.1$ and $0.2 \%)$. Similar results were obtained by Uran \& Yilmaz [2017], who showed no statistically significant differences in the protein content in the control and other groups containing the enzyme in different concentrations $(0.2,0.6$, 0.8 , and $1 \%$ ) during burger production.

\section{Rheological properties}

Minced meat has a plastic-elastic structure characterized by a complex of structural and mechanical properties. The deformation characteristics of the meat system depend on the moisture, fat content, and degree of grinding, and at the biochemical level - on the interaction forces between the functional groups of the molecules.

As a result of rheological studies, the effects of introducing $\mathrm{TG}$ and $\mathrm{BC}$ containing various types of microorganisms on the elastic-plastic properties of the meat system have been established. During the initial stages of ripening, relatively high rates of total and plastic deformation were established in minced meat containing both $5 \%$ and $10 \%$ BC (Table 5), which indicates the softening of the raw meat.

The most pronounced elastic properties were determined in samples S-TG, S-Pro+TG, S-AD+TG, and S-K+TG. Moreover, there was a tendency towards a progressive increase in these indicators with increasing exposure time of the minced meat. The gradient increase in elastic deformation over $24 \mathrm{~h}$ of maturation in the S-TG (from 2.25 to $3.26 \mathrm{~mm}$ ) and S-Pro+TG (from 1.99 to $3.32 \mathrm{~mm}$ ) samples was very clearly observed. The lowest total and plastic deformations in the 12-24 h period were established in the samples with $0.2 \%$ TG at $10.6-12.2 \mathrm{~mm}$ and $8.0-9.8 \mathrm{~mm}$, respectively. In the samples that contained bacterial starters (S-Pro, S-AD, $\mathrm{S}-\mathrm{K})$, a "hopping" change in the elastic properties was observed, with the maximum elastic deformation detected in the $12-18 \mathrm{~h}$ period.

It should be noted that after $12 \mathrm{~h}$ of maturation, the maximum strengthening of the meat system structure occurred under the influence of both TG and microorganism enzymes. The total deformation decreased to $10.57-18.06 \mathrm{~mm}$, plas- 
TABLE 5. Deformation characteristics of minced meat samples.

\begin{tabular}{|c|c|c|c|c|c|}
\hline Samples & $0 \mathrm{~h}$ & $6 \mathrm{~h}$ & $12 \mathrm{~h}$ & $18 \mathrm{~h}$ & $24 \mathrm{~h}$ \\
\hline \multicolumn{6}{|c|}{ Total deformation $(\mathrm{mm})$} \\
\hline S-C & $14.56 \pm 0.12^{\mathrm{abF}}$ & $15.00 \pm 0.355^{\mathrm{aF}}$ & $14.07 \pm 0.049^{\mathrm{bD}}$ & $13.96 \pm 0.038^{\mathrm{bF}}$ & $13.77 \pm 0.152^{\mathrm{bF}}$ \\
\hline S-Pro & $23.10 \pm 0.215^{\mathrm{aBC}}$ & $22.57 \pm 0.474^{\mathrm{aBC}}$ & $16.05 \pm 0.025^{\mathrm{dB}}$ & $19.98 \pm 0.091^{\mathrm{cB}}$ & $21.44 \pm 0.215^{\mathrm{bA}}$ \\
\hline S-AD & $22.48 \pm 0.167^{\mathrm{aCD}}$ & $21.73 \pm 0.271^{\mathrm{aCD}}$ & $15.33 \pm 0.380^{\mathrm{cBC}}$ & $19.12 \pm 0.265^{\mathrm{bC}}$ & $18.65 \pm 0.535^{\mathrm{bB}}$ \\
\hline S-K & $26.28 \pm 0.145^{\mathrm{aA}}$ & $25.63 \pm 0.166^{\mathrm{aA}}$ & $18.06 \pm 0.354^{\mathrm{cA}}$ & $22.01 \pm 0.080^{\mathrm{bA}}$ & $21.06 \pm 0.393^{\mathrm{bA}}$ \\
\hline S-TG & $16.79 \pm 0.040^{\mathrm{aE}}$ & $16.49 \pm 0.173^{\mathrm{aE}}$ & $10.57 \pm 0.240^{\mathrm{cF}}$ & $11.51 \pm 0.205^{\mathrm{bG}}$ & $12.15 \pm 0.101^{\mathrm{bE}}$ \\
\hline $\mathrm{S}-\mathrm{Pro}+\mathrm{TG}$ & $21.90 \pm 0.237 \mathrm{aD}$ & $20.98 \pm 0.225^{\mathrm{bD}}$ & $14.00 \pm 0.063^{\mathrm{eD}}$ & $16.69 \pm 0.090^{\mathrm{dE}}$ & $18.75 \pm 0.118^{\mathrm{cB}}$ \\
\hline $\mathrm{S}-\mathrm{AD}+\mathrm{TG}$ & $23.47 \pm 0.037^{\mathrm{aB}}$ & $23.77 \pm 0.051^{\mathrm{aB}}$ & $12.93 \pm 0.099^{\mathrm{dE}}$ & $17.16 \pm 0.113^{\mathrm{cE}}$ & $18.07 \pm 0.126^{\mathrm{bBC}}$ \\
\hline $\mathrm{S}-\mathrm{K}+\mathrm{TG}$ & $22.37 \pm 0.251^{\mathrm{aCD}}$ & $21.74 \pm 0.333^{\mathrm{aCD}}$ & $14.83 \pm 0.075^{\mathrm{cCD}}$ & $17.87 \pm 0.079^{\mathrm{bD}}$ & $17.14 \pm 0.396^{\mathrm{bC}}$ \\
\hline \multicolumn{6}{|c|}{ Plastic deformation ( $\mathrm{mm}$ ) } \\
\hline S-C & $13.53 \pm 0.232^{\mathrm{aC}}$ & $12.82 \pm 0.353^{\mathrm{abA}}$ & $11.88 \pm 0.349^{\mathrm{bcC}}$ & $12.03 \pm 0.084^{\mathrm{bcD}}$ & $11.21 \pm 0.199^{\mathrm{cD}}$ \\
\hline S-Pro & $21.86 \pm 0.223^{\mathrm{aA}}$ & $20.43 \pm 0.368^{\mathrm{bBC}}$ & $12.71 \pm 0.162^{\mathrm{eB}}$ & $16.95 \pm 0.105^{\mathrm{dB}}$ & $18.51 \pm 0.190^{\mathrm{cA}}$ \\
\hline S-AD & $20.82 \pm 0.132^{\mathrm{aAB}}$ & $19.58 \pm 0.308^{\mathrm{aB}}$ & $12.28 \pm 0.320^{\mathrm{cB}}$ & $14.22 \pm 0.147^{\mathrm{bC}}$ & $15.58 \pm 0.657^{\mathrm{bB}}$ \\
\hline S-K & $24.75 \pm 0.107^{\mathrm{aD}}$ & $23.92 \pm 0.191^{\mathrm{aE}}$ & $15.66 \pm 0.398^{\mathrm{cA}}$ & $19.42 \pm 0.247^{\mathrm{bA}}$ & $18.60 \pm 0.472^{\mathrm{bA}}$ \\
\hline S-TG & $14.38 \pm 0.215^{\mathrm{aC}}$ & $13.62 \pm 0.192^{\mathrm{bD}}$ & $8.00 \pm 0.127^{\mathrm{eE}}$ & $9.81 \pm 0.073^{\mathrm{cE}}$ & $8.88 \pm 0.041^{\mathrm{dE}}$ \\
\hline $\mathrm{S}-\mathrm{Pro}+\mathrm{TG}$ & $19.64 \pm 0.229^{\mathrm{aB}}$ & $18.56 \pm 0.216^{\mathrm{bB}}$ & $10.96 \pm 0.064^{\mathrm{eCD}}$ & $12.52 \pm 0.065^{\mathrm{dD}}$ & $15.58 \pm 0.087^{\mathrm{cB}}$ \\
\hline $\mathrm{S}-\mathrm{AD}+\mathrm{TG}$ & $21.91 \pm 0.030^{\mathrm{aA}}$ & $21.38 \pm 0.024^{\mathrm{bC}}$ & $9.79 \pm 0.084^{\mathrm{eD}}$ & $12.25 \pm 0.195^{\mathrm{dD}}$ & $15.03 \pm 0.142^{\mathrm{cB}}$ \\
\hline $\mathrm{S}-\mathrm{K}+\mathrm{TG}$ & $19.49 \pm 0.183^{\mathrm{aB}}$ & $19.56 \pm 0.398^{\mathrm{aB}}$ & $12.02 \pm 0.066^{\mathrm{cB}}$ & $14.97 \pm 0.060^{\mathrm{bC}}$ & $13.92 \pm 0.317^{\mathrm{bC}}$ \\
\hline \multicolumn{6}{|c|}{ Elastic deformation (mm) } \\
\hline $\mathrm{S}-\mathrm{C}$ & $1.986 \pm 0.040^{\mathrm{cB}}$ & $2.188 \pm 0.002^{\mathrm{bcB}}$ & $2.683 \pm 0.146^{\mathrm{aBC}}$ & $2.369 \pm 0.052^{\mathrm{abB}}$ & $2.652 \pm 0.054^{\mathrm{aDE}}$ \\
\hline S-Pro & $2.024 \pm 0.048^{\mathrm{cAB}}$ & $2.142 \pm 0.107^{\mathrm{cB}}$ & $3.339 \pm 0.188^{\mathrm{aA}}$ & $3.118 \pm 0.044^{\mathrm{abA}}$ & $2.796 \pm 0.085^{\mathrm{bCD}}$ \\
\hline S-AD & $1.930 \pm 0.037^{\mathrm{bB}}$ & $2.156 \pm 0.072^{\mathrm{bB}}$ & $3.050 \pm 0.061^{\mathrm{aAB}}$ & $3.028 \pm 0.062^{\mathrm{aA}}$ & $3.074 \pm 0.123^{\mathrm{aAC}}$ \\
\hline S-K & $1.583 \pm 0.068^{\mathrm{bC}}$ & $1.708 \pm 0.025^{\mathrm{bC}}$ & $2.400 \pm 0.114^{\mathrm{aC}}$ & $2.194 \pm 0.029^{\mathrm{aB}}$ & $2.459 \pm 0.083^{\mathrm{aE}}$ \\
\hline S-TG & $2.254 \pm 0.043^{\mathrm{dA}}$ & $2.828 \pm 0.020^{\mathrm{cA}}$ & $3.074 \pm 0.047^{\mathrm{bAB}}$ & $3.089 \pm 0.027^{\mathrm{bA}}$ & $3.260 \pm 0.032^{\mathrm{aA}}$ \\
\hline $\mathrm{S}-\mathrm{Pro}+\mathrm{TG}$ & $1.998 \pm 0.068^{\mathrm{dB}}$ & $2.414 \pm 0.008^{\mathrm{cB}}$ & $3.046 \pm 0.061^{\mathrm{bAB}}$ & $3.007 \pm 0.055^{\mathrm{bA}}$ & $3.318 \pm 0.071^{\mathrm{aA}}$ \\
\hline $\mathrm{S}-\mathrm{AD}+\mathrm{TG}$ & $2.115 \pm 0.069^{\mathrm{cAB}}$ & $2.390 \pm 0.075^{\mathrm{bB}}$ & $3.241 \pm 0.052^{\mathrm{aA}}$ & $3.180 \pm 0.047^{\mathrm{aC}}$ & $3.050 \pm 0.016^{\mathrm{aAC}}$ \\
\hline $\mathrm{S}-\mathrm{K}+\mathrm{TG}$ & $1.956 \pm 0.029^{\mathrm{bB}}$ & $2.180 \pm 0.065^{\mathrm{bB}}$ & $2.915 \pm 0.159^{\mathrm{aAC}}$ & $3.008 \pm 0.055^{\mathrm{aA}}$ & $2.928 \pm 0.052^{\mathrm{aC}}$ \\
\hline
\end{tabular}

Note: data are the mean values of five replicates \pm standard deviation $(n=5)$. Means in a row without a common superscript letter a, b, $c-$ are statistically significantly different $(p<0.05)$. Means in a column without a common superscript letter A, B, C - are statistically significantly different $(p<0.05)$ as analyzed by one-way ANOVA and the TUKEY test.

S-C - control sample; S-Pro, S-AD, S-K - samples with the addition of 10\% concentrate Bifilact-Pro, Bifilact-AD, Bifilact-Kefir; S-TG - samples with the addition of $0.2 \%$ transglutaminase; S-Pro + TG, S-AD+TG, S-K+TG - samples with the addition of $0.1 \%$ transglutaminase and 5\% Bifilact-Pro, Bifilact-AD, Bifilact-Kefir.

tic deformation was up to $8.00-15.66 \mathrm{~mm}$, and the extent of elastic deformation was 2.40-3.34 mm. Canto et al. [2014] reported that the increase in springiness and cohesiveness of meat systems containing TG might have been due to the enhanced protein cross-linking between particles of meat. A gradual decrease in total and plastic deformation and an increase in elastic deformation during the ripening period were observed in the control sample.

During the entire ripening period $(24 \mathrm{~h})$, it was noted that the S-K and S-Pro samples were characterized by the least elasticity and most pronounced plasticity. The observed changes were caused by the proteolytic activity of microorganisms in the composition of $\mathrm{BC}$ capable of polypeptides release, which leads to the relaxation of raw meat structure. Nevertheless, with the combined use of starter microorganisms and TG involved in the binding of food systems biopolymers, all samples of minced meat showed an improvement in both the plastic and elastic properties. As a result, the meat system with developed elastic-plastic properties can be easily moulded into a dense monolithic structure, subsequently 
forming the elastic consistency of the meat product. Ionescu et al. [2008] showed that the increase in viscosity of myofibrillar protein with TG treatment is due to protein chain cross-linking catalyzed by TG. The cross-linkage between TG and protein can affect the viscosity of food system, making it stiffer and more rigid than the control. Lesiow et al. [2017] demonstrated that the presence of TG increased the hardness of control pork meat batters. The interactions of proteins and water have important effects on water holding and gelling in meat products, and consequently on their technological properties.

\section{CONCLUSIONS}

The results of the studies showed a unidirectional positive effect of TG and $\mathrm{BC}$ on the functional and technological properties of the meat system. It has been determined that a ripening time of $12-18 \mathrm{~h}$ is sufficient for the development of optimal WBC, WHC and rheological properties of minced meat with the addition of TG and $\mathrm{BC}$. The results of this research indicate that the meat industry may achieve the benefits of improved technological properties and reduced cooking loss by using a combination of $\mathrm{BC}$ with $\mathrm{TG}$ in their formulations.

\section{RESEARCH FUNDING}

The article was prepared with the support of the Government of the Russian Federation (Act No 211 dd. 16.03.2013), Contract No 02.A03.21.0011, and the financial support of state assignments No 40.8095.2017/БЧ (2017123-ГЗ), No 19.8259.2017/ß'4 and RFBR grant No 18-53-45015.

\section{CONFLICT OF INTEREST}

The authors declare no conflicts of interest.

\section{REFERENCES}

1. Aaslyng, M.D., Bejerholm, C., Ertbjerg, P., Bertram H.C., Andersen H.J. (2003). Cooking loss and juiciness of pork in relation to raw meat quality and cooking procedure. Food Quality and Preference, 14(4), 277-288.

2. Assaad, H., Zhou, L., Carroll, R.J., Wu, G. (2014). Rapid publication-ready MS-Word tables for one-way ANOVA. Springer Plus, 3, art. no. 474.

3. Atilgan, E., Kilic, B. (2017). Effects of microbial transglutaminase, fibrimex and alginate on physicochemical properties of cooked ground meat with reduced salt level. Journal of Food Science and Technology, 54(2), 303-312.

4. Baugreet, S., Kerry, J.P., Brodkorb, A., Gomez, C., Auty, M., Allen, P., Hamill, R.M. (2018). Optimisation of plant protein and transglutaminase content in novel beef restructured steaks for older adults by central composite design. Meat Science, 142, 65-77.

5. Campbell-Platt, G. (1995). Fermented meats - a world perspective. In: G. Campbell-Platt, P.E. Cook (Eds.) Fermented Meats. Chapman \& Hall, Glasgow, pp. 39-52.
6. Canto, A.C.V.C.S., Costa Lima, B.R.C., Suman, S.P., Lazaro, C.A., Monteiro, M.L.G., Conte-Junior, C.A., Freitas, M.Q., Cruz, A.G. (2014). Physico-chemical and sensory attributes of low-sodium restructured caiman steaks containing microbial transglutaminase and salt replacers. Meat Science, 96(1), 623-632 .

7. Cerning, J. (1995). Production of exopolysaccharides by lactic acid bacteria and dairy propionibacteria. Lait, 75(4-5), 463-472.

8. Cheng, F.Y., Hsu, F.W., Chang, H.S., Lin, L.C., Sakata, R. (2009). Effect of different acids on the extraction of pepsin-solubilised collagen melanin from silky fowl feet. Food Chemistry, 113(2), 563-567.

9. Danylenko, S.G., Kigel, N.Ph., Burtseva, G.V. (2014). Selection of microorganisms for fermentation of raw materials. Biotechnologia Acta, 7(4), 107-117.

10. Djabourov, M., Lechaire, J., Gaill, F. (1993). Structure and rheology of gelatin and collagen gels. Biorheology, 30(3-4), 191-205.

11. Doleyres, Y., Schaub, L., Lacroix, C. (2005). Comparison of functionality of exopolysaccharides produced in situ or added as bioingredients on yoghurt properties. Journal of Dairy Science, 88(12), 4146-4156.

12. El Soda, M. (2014). Production of low fat cheddar cheese made using exopolysaccharide-producing cultures and selected ripening cultures. Advances in Microbiology, 04(14), 986-995.

13. Grau, R., Hamm, R. (1956). Die bestimmung der wasserbindung des fleisches mittles der premethode. Fleischwirtsch, 8, 733-734.

14. Hammes, W.P., Hertel, C. (1998). New developments in meat starter cultures. Meat Science, 49, S125-S138.

15. Hughes, J.M., Oiseth, S.K., Purslow, P.P. Warner, R.D. (2014). A structural approach to understanding the interactions between colour, water-holding capacity and tenderness. Meat Science, 98(3), 520-532.

16. Ionescu, A., Aprodu, I., Darabă, A. (2008). The effects of transglutaminase on the functional properties of the myofibrillar protein concentrate obtained from beef heart. Meat Science, 79(2), 278-284.

17. ISO 937:1978. Meat and meat products - Determination of nitrogen content. Geneva: International Organization for Standardization.

18. ISO 1442:1997. Meat and meat products - Determination of moisture content (Reference method). Geneva: International Organization for Standardization.

19. ISO 1444:2000. Meat and meat products - Determination of free fat content. Geneva: International Organization for Standardization.

20. Kieliszek, M., Misiewicz, A. (2014). Microbial transglutaminase and its application in the food industry: A review. Folia Microbiologica, 59(3), 241-250

21. Lesiow, T., Rentfrow, G.K., Xiong, Y.L. (2017). Polyphosphate and myofibrillar protein extract promote transglutaminase-mediated enhancements of rheological and textural properties of PSE pork meat batters. Meat Science, 128, 40-46.

22. Liu, D., Liang, L., Regenstein, J.M. Zhou, P. (2012). Extraction and characterisation of pepsin-solubilised collagen from fins, scales, skins, bones and swim bladders of bighead carp (Hypophthalmichthys nobilis). Food Chemistry, 133(4), 1441-1448.

23. Mauriello, G., Casaburi, A., Blaiotta, G., Villani, F. (2004). Isolation and technological properties of coagulase negative Staphy- 
lococci from fermented sausages of Southern Italy. Meat Science, 67(1), 149-158.

24. Meiying, Z., Guocheng, D., Jian, C. (2002). pH control strategy of batch microbial transglutaminase production with Streptoverticillium mobaraense. Enzyme and Microbial Technology, 31(4), 477-481.

25. Mejri, L., Ziadi, A., El Adab, S., Boulares, M., Essi, I., Hassouna, M. (2017). Effect of commercial starter cultures on physicochemical, microbiological and textural characteristics of a traditional dry fermented sausage reformulated with camel meat and hump fat. Journal of Food Measurement and Characterization, 11(2), 758-767.

26. Patel, S., Majumder, A., Goyal, A. (2012). Potentials of exopolysaccharides from lactic acid bacteria. Indian Journal of Microbiology, 52(1), 3-12.

27. Pietrasik, Z., Jarmoluk, A., Shand, P.J. (2007). Effect of nonmeat proteins on hydration and textural properties of pork meat gels enhanced with microbial transglutaminase. $L W T-$ Food Science Technology, 40(5), 915-920.

28. Puolanne, E., Peltonen, J. (2013). The effects of high salt and low $\mathrm{pH}$ on the water-holding of meat. Meat Science, 93(2), 167-170.

29. Rawdkuen, S., Benjakul, S. (2012). Biochemical and microstructural characteristics of meat samples treated with different plant proteases. African Journal of Biotechnology, 11 (76), 14088-14095 .

30. Rivier, N., Sadoc, J.F. (2007). Topology in Molecular Biology. Springer, Berlin Heidelberg, pp. 147-162.

31. Ruas-Madiedo, P., Moreno, J.A., Salazar, N., Delgado, S., Mayo, B., Margolles, A., Reyes-Gavilán, C.G.L. (2007). Screening of exopolysaccharide-producing Lactobacillus and Bifidobacterium strains isolated from the human intestinal microbiota. Applied and Environmental Microbiology, 73(13), 4385-4388.

32. Ruiz-Moyano, S., Martin, A., Benito, M.J. Nevado, F.P., Córdoba, M.G. (2008). Screening of lactic acid bacteria and bifidobac- teria for potential probiotic use in Iberian dry fermented sausage. Meat Science, 80(3), 715-721.

33. Sanni, A.I., Onilude, A.A., Ogunbanwo, S.T. Fadahunsi, I.F., Afolabi, R.O. (2002). Production of exopolysaccharides by lactic acid bacteria isolated from traditional fermented foods in Nigeria. European Food Research and Technology, 214(5), 405-407.

34. Sorapukdee, S., Tangwatcharin, P. (2018). Quality of steak restructured from beef trimmings containing microbial transglutaminase and impacted by freezing and grading by fat level. Asian-Australasian Journal of Animal Sciences, 31 (1), 129-137.

35. Tseng T.F., Cheng M.T., Liu, D.C. (2002). Purification of transglutaminase and its effects on myosin heavy chain and actin of spent hens. Meat Science, 60(3), 267-270.

36. Uran, H., Aksu, F., Gokce, İ., Yilmaz, İ., Durak, M.Z. (2013). Effect of transglutaminase on the quality properties of chicken breast patties. Kafkas Universitesi Veteriner Fakultesi Dergisi, 19, 331-335.

37. Uran, H., Yilmaz, İ. (2018). A research on determination of quality characteristics of chicken burgers produced with transglutaminase supplementation. Food Science and Technology (Campinas), 38(1), 19-25.

38. Yokoyama, K., Nio, N., Kikuchi, Y. (2004). Properties and applications of microbial transglutaminase. Applied Microbiology and Biotechnology, 64(4), 447-454.

39. Zeng, Z., Li, Ch., Ertbjerg, P. (2017). Relationship between proteolysis and water-holding of myofibrils. Meat Science, 131, 48-55.

40. Zhang, X.W., Wang, W.H., Wang, Y.N., Wang, Y.B., Wang, X., Gao, G.Y., Chen, G.Y., Liu, A.J. (2018). Effects of nanofiber cellulose on functional properties of heat-induced chicken salt-soluble meat protein gel enhanced with microbial transglutaminase. Food Hydrocolloids, 84, 1-8.

Submitted: 13 March 2019. Revised: 22 May and 13 July 2019. Accepted: 21 August 2019. Published on-line: 1 October 2019. 